OLEKSANDR SHEVCHENKO

ORCID: 0000-0002-9996-0444

e-mail: oshevchenko349@gmail.com

\title{
Idea Sojuszu Bałtycko-Czarnomorskiego oraz reakcja na utworzenie Trójmorza w ukraińskiej myśli politycznej 2015-2019
}

The idea of the 'Baltic and Black Sea Alliance' and the reaction to the creation of the Three Seas Initiative in Ukrainian political thought between 2015 and 2019

Słowa kluczowe: Ukraina, Inicjatywa Trójmorza, Polska, relacje ukraińsko-polskie
Keywords:

Ukraine, Three Seas

Initiative, Poland, Polish-Ukrainian relations 
The idea of the 'Baltic and Black Sea Alliance' and the reaction to the creation of the Three Seas Initiative in Ukrainian political thought between 2015 and 2019

In 2015, most Ukrainian political observers took Andrzej Duda's words about the possibility of establishing a regional initiative as a renewal of the idea of Intermarium, a topic publicly discussed and debated in Ukraine since the 1990 s but which has become particularly relevant since the 2014 Revolution of Dignity. Therefore, the creation of the Three Seas Initiative in 2016 without Ukraine's participation came as a surprise to Ukrainian political thought. In this article, the author describes the most characteristic and relevant opinions of Ukrainian politicians, scientists and journalists about the Three Seas Initiative. The analysis of the response of Ukrainian politicians makes it possible to create an objective picture of how Ukrainian political thought reacted to the creation and activity of the Three Seas Initiative, which has a significant impact on the further development of Ukraine's regional policy and on Polish-Ukrainian relations. 
Drezydent Ukrainy Wołodymyr Zełenski w ciągu pierwszego roku swojej kadencji podkreślał chęć dołączenia do inicjatywy Trójmorza. W pewnym sensie jest to naturalny skutek recepcji tej idei w ukraińskiej myśli politycznej w ciągu kilku ostatnich lat. Celem proponowanego czytelnikowi artykułu jest przedstawienie, w jaki sposób idea utworzenia i działalności Trójmorza została przyjęta na Ukrainie oraz jaki miała wpływ na kształtowanie się ukraińskiego dyskursu o współpracy na osi bałtycko-czarnomorskiej, który pojawił się na Ukrainie w latach dziewięćdziesiątych i istnieje do dzisiaj. Stan badań naukowych nad podejmowaną w artykule tematyką jest mało zaawansowany. W polskiej literaturze naukowej są opracowania opisujące istotę Trójmorza, brakuje jednak studiów nad recepcją tej idei wśród partnerów Polski. W niniejszym tekście autor stara się częściowo uzupełnić tę lukę.

\section{Cztery definicje idei sojuszu państw pomiędzy Morzem Bałtyckim a Morzem Czarnym}

W krótkim wstępie teoretycznym wyjaśnię cztery zasadnicze pojęcia, którymi będę się posługiwał. Są to Sojusz Bałtycko-Czarnomorski, idea federacyjna Józefa Piłsudskiego, Międzymorze oraz Trójmorze.

Sojusz Bałtycko-Czarnomorski - pojęcie to zakotwiczone jest w ukraińskiej myśli politycznej, a jego korzenie sięgają pomysłów Mychajła Hruszewskiego (chodzi o jego ideę Federacji Czarnomorskiej, którą szczegółowo opisał historyk Hennadij Koroljow ${ }^{1}$ ) i Jurija Łypy (Doktryna Czarnomorska przedstawiona przez niego w $1940 \mathrm{r}^{2}$ ). Chodziło w nim o ewentualny sojusz polityczno-wojskowy między Ukrainą, Polską, Białorusią i państwami bałtyckimi. Właśnie do tej idei odwołuje się większość ukraińskich analityków piszących na ten temat oraz centra badawcze, o których będę wspominał w artykule.

Idea federacyjna Józefa Piłsudskiego to program marszałka Piłsudskiego, z którym występował w 1918 r., kiedy Polska odzyskiwała niepodległość. Pomysł federacji kilku równych narodów według Pawła Kowala sięga

1 H. O. Korolow, Ideja czornomorśkoji federaciji u pohladach Mychajła Hruszewśkoho // „Ukrajinśkyj istorycznyj żurnał” 2011, issue 6, s. 68-79.

2 J. Łypa, Czornomorśka doktryna, Biblioteka ukrajinoznawstwa; wyp. 12, MAUP, Kyjiw 2007. 
jeszcze czasów niezrealizowanej unii hadziackiej, zawartej w 1658 r. Później idea ta pojawiła się $\mathrm{w}$ trakcie przygotowań do powstania styczniowego 1863 r., której to tradycji kontynuatorem w polskiej myśli politycznej był Józef Piłsudski ${ }^{3}$.

Międzymorze to $\mathrm{z}$ kolei pojęcie bardzo przydatne $\mathrm{w}$ niniejszej analizie. Był to program, który pojawił się m.in. w związku z niemożnością zrealizowania idei federacyjnej. Różnica między programem federacyjnym Piłsudskiego a koncepcją Międzymorza polega na nieobecności w programie Międzymorza państw, których dotyczyć miała idea federacyjna, oraz stopnia integracji, jej kontekstu historycznego i innych szczegółowych kwestii. Nową myśl między programem federacyjnym a ideą Międzymorza stanowi generalne stwierdzenie o konieczności podejmowania prób integracji w Europie Środkowej i Wschodniej ${ }^{4}$. Paweł Kowal wydziela cztery etapy rozwoju koncepcji Międzymorza. Pierwszym Międzymorzem nazywa on właśnie ten program, który pojawił się po podpisaniu traktatu ryskiego ze względu na konieczność poszukiwania nowych formuł współpracy w Europie Środkowej na miejsce idei federacyjnej. Ciąg polskich pomysłów nazywanych przez Pawła Kowala pierwszym Międzymorzem kończy się z początkiem II wojny światowej, która zmieniła mapę Europy, a co za tym idzie - w znaczącym stopniu wpłynęła na sytuację międzynarodową. Drugim Międzymorzem Paweł Kowal nazywa zabiegi Władysława Sikorskiego o głębszą współpracę w regionie Europy Środkowo-Wschodniej w latach 1939-1943. Trzecie Międzymorze to pomysł polskiej opozycji na początku lat osiemdziesiątych, wyrażony m.in. w czasopismach „Obóz” i „ABC. Adriatyk, Bałtyk, Morze Czarne". W końcu pojawia się czwarte Międzymorze, czyli współczesna idea, z którą wystąpił Andrzej Duda w kampanii wyborczej w 2015 r. i która później przekształciła się w projekt Trójmorza 5 .

Trójmorze to $\mathrm{z}$ kolei międzynarodowa inicjatywa polityczno-gospodarcza, powołana w 2015 r. i łącząca 12 państw Unii Europejskiej położonych nad morzami Adriatyckim, Bałtyckim i Czarnym (ABC).

Tradycyjnie w ukraińskiej myśli politycznej pojęcie Sojuszu Bałtycko-Czarnomorskiego było ściśle powiązane z pojęciem Międzymorza - niejednokrotnie uznawano, że jest to w zasadzie ten sam pomysł, który

3 P. Kowal, A. Orzelska-Stączek, Inicjatywa Trójmorza: geneza, cele, funkcjonowanie, Instytut Studiów Politycznych PAN, Warszawa 2019, s. 20.

4 Tamże, s. 22.

5 Tamże, s. 22-42. 
się pojawił niemal jednocześnie w ukraińskiej i polskiej myśli politycznej ${ }^{6}$. Inicjatywa Trójmorza również została odebrana jako kontynuacja tego samego pomysłu, co będzie widać $\mathrm{w}$ wyniku analizy przedstawionych poniżej tekstów. Dlatego naturalne jest powiązanie analizy ukraińskiej myśli politycznej w odniesieniu do ewentualnego odnowienia idei Sojuszu Bałtycko-Czarnomorskiego z reakcją na utworzenie Trójmorza.

\section{Idea Sojuszu Bałtycko-Czarnomorskiego w ukraińskiej myśli politycznej 2015-2019}

Temat Sojuszu Bałtycko-Czarnomorskiego stał się szczególnie popularny na Ukrainie po tzw. rewolucji godności 2013/2014. Był to efekt nowej rzeczywistości geopolitycznej i potrzeby poszukiwania formuły w polityce zagranicznej.

Jeszcze podczas kampanii przed wyborami parlamentarnymi w 2014 r. wzmocnienie współpracy na połączeniu bałtycko-czarnomorskim było wymienione jako priorytet polityki zagranicznej Ukrainy m.in. w programie partii Swoboda ${ }^{7}$. Szerzej tym regionem interesowała się partia Prawy Sektor. W jej programie znajdziemy tezę, że priorytetem ma być realizacja „ukraińskiej strategii na osi Bałtyk-Zakaukazie”.

W kształtowaniu poglądów Ukraińców w kwestii omawianego sojuszu duży wpływ miał Walerij Majdaniuk. W artykule z kwietnia 2014 r. pisał on, że w warunkach biernej polityki UE i USA w stosunku do agresywnej polityki Rosji Ukraina musi się orientować właśnie na państwa osi bałtycko-czarnomorskiej.

Żaden kraj Europy Zachodniej nie ma zamiaru powstrzymać agresji militarnej Rosji przeciwko suwerennemu państwu demokratycznemu

6 Wyraźnym przykładem traktowania Sojuszu Bałtycko-Czarnomorskiego i Międzymorza jako tego samego pomysłu jest np. artykuł Andrija Zbrucza na stronie internetowej Prawego Sektora. A.Zbrucz, Ideja Batto-Czornomorśkoho Sojuzu (Miżmorja): istorija ta perspektywy [online], 25 V 2017 [dostęp: 14 VI 2020], dostępny w internecie: <https://pravyysektor.info/prosvitnyctvo/oriyentyry/ ideya-balto-chornomorskogo-soyuzu-mizhmorya-istoriya-ta-perspektyvy $\rangle$.

7 Program wyborczy partii Swoboda, Centralna Komisja Wyborcza [online], 22 IX 2014 [dostęp: 2 VI 2019], dostępny w internecie: 〈https://www.cvk.gov.ua/pls/vnd2014/ wp502ptoo1fo1 $=910$ ff $7171=155 . \mathrm{html}>$.

8 Program wyborczy partii Prawy Sektor, Centralna Komisja Wyborcza [online], 26 X 2014 [dostęp: 17 X 2020], dostępny w internecie: 〈https://www.cvk.gov.ua/pls/ vnd2014/wp502ptoolfo1=910pf $7171=158 . \mathrm{html}>$. 
w centrum Europy, ograniczając się do sankcji deklaratywnych. Jedynymi państwami wzywającymi do wsparcia militarnego Ukrainy są Polska i kraje bałtyckie. Właśnie to powinien być nowy wektor polityki zagranicznej dla Ukraińców ${ }^{9}$

- pisał Majdaniuk. Szczególną rolę w utworzeniu nowego sojuszu Majdaniuk przypisywał Polsce, ponieważ według autora sojusz ten odpowiada w najwyższym stopniu właśnie polskim interesom geopolitycznym:

Istnieją poważne podstawy do zawarcia sojuszu obronnego z sąsiadami z regionu w Polsce, która ma już historyczne przykłady „pomocy” aliantów zachodnich w roku 1939 oraz od 1945 do 1989 r. Według niego podczas gdy Niemcy i Francja liczą na pieniądze od partnerstwa z Rosją, nie widząc w niej zagrożenia dla własnego bezpieczeństwa, dla Polski powstrzymywanie Rosji jest kwestią przetrwania, wymagającą pełnego poparcia dla Ukrainy. Polska i Litwa są jedynymi państwami rozważającymi wsparcie wojskowe dla Ukrainy w obronie przed rosyjską agresją ${ }^{10}$.

W roku 2017 Majdaniuk - z pomocą Fundacji Wsparcia Inicjatyw Demokratycznych - stał się założycielem Centrum Informacyjnego Międzymorze, które skutecznie pełni funkcję informacyjną, ale również wspiera organizowanie dyskusji i konferencji oraz wydawanie książek poświęconych idei utworzenia Sojuszu Bałtycko-Czarnomorskiego ${ }^{11}$.

Co ciekawe, w roku 2017 Oksana Jurynec, ówczesna posłanka Rady Najwyższej Ukrainy z Bloku Petra Poroszenki, prawie słowo w słowo powtarzała tezy z przytoczonego artykułu Majdaniuka (przypomnę, że jego tekst powstał trzy lata wcześniej). Wystąpienie Jurynec podczas obrad okrągłego stołu „Sojusz Bałtycko-Czarnomorski: od mitu do rzeczywistości” opublikowano w zbiorze pokonferencyjnym ${ }^{12}$.

9 Batto-Czornomorśkyj Sojuz, jak alternatywa zachidnomu wektoru, Informacyjna agencja "Whołos" [online], 13 IV 2014 [dostęp: 2 XI 2019], dostępny w internecie: <https://vgolos.com.ua/articles/balto-chornomorskyj-soyuz-yak-alternatyva-shidnozahidnomu-vektoru_142465.html $>$.

10 Tamże.

11 Informacijnyj centr „Miżmorja" - pro nas, Informacijnyj centr „Miżmorja” [online, dostęp: 2 XI 2019], dostępny w internecie: 〈https://intermarium.in.ua/about/〉.

12 O. W. Juryneć, Nowi heopolityczni wykłyky jak pidstawa formuwannia BałtijśkoCzornomorśkoji Osi // Bałto-Czornomorśkyj Sojuz: wid mifu do realnosti, Kyjiw 2017, s. 3-4. 
Centrum Informacyjne Międzymorze nie jest jedyną organizacją poświęconą współpracy na osi bałtycko-czarnomorskiej, utworzoną po rewolucji godności. W 2015 r. powstała pozarządowa Konfederacja Bałtycko-Czarnomorska. Jej założycielem został biznesmen Wadym Mariuchnycz ${ }^{13}$. W grudniu 2015 r. opublikowano artykuł eksperta Konfederacji, prawnika Andrija Firusa, który pisał o prawniczych aspektach możliwości utworzenia Konfederacji Bałtycko-Czarnomorskiej. Autor, jak i inni (w tym Majdaniuk), krytykował państwa Europy Zachodniej za pasywność w walce dyplomatycznej przeciwko Rosji i widział skuteczne rozwiązanie właśnie w utworzeniu związku państw osi bałtycko-czarnomorskiej (konkretnie pisał tutaj o konfederacji jako najwyższym poziomie integracji państw regionu). Z prawniczego punktu widzenia Firus uważał, że najskuteczniejsze byłoby utworzenie organizacji międzynarodowej, która nie potrzebowałaby zatwierdzenia ani ze strony UE, ani ze strony NATO:

\begin{abstract}
Jedyną szybką opcją, która daje szansę na utworzenie konfederacji lub związku na podstawie międzypaństwowych traktatów, jest powołanie Międzynarodowej Organizacji Regionu Morza Bałtyckiego i Morza Czarnego. Pozwoli ona poszczególnym państwom członkowskim Unii Europejskiej stać się członkami tej organizacji bez zgody na ich przystąpienie ze strony innych państw członkowskich UE. Nie będzie to sprzeczne z Traktatem o Unii Europejskiej i Traktatem o funkcjonowaniu Unii Europejskiej. Decyzja o przystąpieniu do tej organizacji któregoś z krajów nie leży w kompetencjach UE i Trybunału Sprawiedliwości UE ${ }^{14}$.
\end{abstract}

W maju 2016 r. organizacja ta stała się inicjatorem i głównym organizatorem konferencji międzynarodowej zatytułowanej „Utworzenie Międzynarodowego Konfederacyjnego Związku i zbudowanie Konfederacji Bałtycko-Czarnomorskiej" w Hadziaczu (miasto w północno-wschodniej Ukrainie; w 1658 r. właśnie tam zawarta została unia między Rzecząpospolitą a wojskiem zaporoskim, dlatego wybór miejsca nie jest

13 Hromadśka orhanizacija Baltijśko-Czornomorśka Konfederacija, YouControl [online], 23 II 2015 [dostęp: 17 XI 2019], dostępny w internecie: <https://youcontrol.com.ua/ catalog/company_details/39653694/>.

14 Jurydyczni aspekty utworennia Bałtijśko-Czornomorśkoji Konfederaciji, ar25.org [online], 1 XII 2015 [dostęp: 17 XI 2019], dostępny w internecie: <https://www.ar25.org/article/ yurydychni-aspekty-utvorennya-baltiysko-chornomorskoyi-konfederaciyi.html $\rangle$. 
przypadkowy, stanowi bowiem odwołanie się do tych historycznych wydarzeń). W konferencji uczestniczyli m.in. posłanka Oksana Jurynec oraz drugi sekretarz ambasady RP na Ukrainie ${ }^{15}$.

Najaktywniejszą organizacją poświęconą współpracy na osi bałtycko-czarnomorskiej stało się jednak Międzynarodowe Centrum Badań Bałtycko-Czarnomorskich, utworzone w styczniu 2016 r. Już 1 grudnia 2016 r. w Kijowie odbyło się pierwsze Forum Bałtycko-Czarnomorskie organizowane przez Centrum. W wydarzeniu wzięli udział byli prezydenci państw osi bałtycko-czarnomorskiej, w tym prezydenci Ukrainy: Leonid Krawczuk i Leonid Kuczma oraz były prezydent RP Lech Wałęsa.

\begin{abstract}
Jesteśmy przekonani, że połączywszy wysiłki narodów przestrzeni bałtycko-czarnomorskiej, w obecnych warunkach jesteśmy w stanie wypracować nową metodologię i praktykę moralnej oceny przeszłości, skutecznej transformacji teraźniejszości i całościowej wizji godnej przyszłości ${ }^{16}$
\end{abstract}

- podkreślili we wspólnym wystąpieniu uczestnicy forum.

W drugim forum, które odbyło się w Kownie w marcu 2017 r., uczestniczyli już trzej prezydenci Ukrainy (Leonid Krawczuk, Leonid Kuczma i Wiktor Juszczenko) oraz trzej prezydenci Polski (Lech Wałęsa, Aleksander Kwaśniewski, Bronisław Komorowski) ${ }^{17}$. Do uczestników trzeciego forum z tego cyklu (w czerwcu 2017 r. w Kijowie) specjalne przesłanie wystosował ówczesny prezydent Ukrainy Petro Poroszenko, co można interpretować jako uznanie dla działań Międzynarodowego Centrum. W rezultacie tego forum podjęto decyzję o utworzeniu stałej struktury (pod nazwą Platforma Uniwersytetów), która miałaby łączyć badaczy państw regionu ${ }^{18}$.

15 Miżnarodna konferencija w Hadiaczi, oficjalna strona internetowa Hadziackiego rejonu [online, dostęp: 17 XI 2019], dostępny w internecie: <http://www.hadiach-rajon-vlada.org.ua/index.php/1899-mizhnarodna-konferentsiya-u-gadyachi $\rangle$.

16 Zajawa uczasnykiw 1-ho Battijśko-Czornomorśkoho Forumu Konfederacija [online] 1 XII 2016 [dostęp: 17 XI 2019], dostępny w internecie: <https://centrebbs.org/fr/ pervyj-forum/>.

17 Druhyj Battijśko-Czornomorśkyj Forum [online], 10 III 2017 [dostęp: 17 XI 2019], dostępny w internecie: 〈https://centrebbs.org/fr/vtoroj-forum/〉.

18 Tretij Battijśko-Czornomorśkyj Forum [online], 23 VI 2017 [dostęp: 17 XI 2019], dostępny w internecie: 〈https://centrebbs.org/fr/tretij-forum/>. 
Do października 2019 r. odbyło się sześć spotkań w formacie Forum Bałtycko-Czarnomorskiego. Mimo że te spotkania nie są formalnie wiążące dla polityków, sama obecność byłych prezydentów sprawiła, że ideą Sojuszu Bałtycko-Czarnomorskiego zainteresowały się media. Latem 2019 r. założycielka i prezydent Centrum Iryna Wereszczuk została posłanką Rady Najwyższej Ukrainy z ramienia partii Sługa Narodu.

Myśl polityczna ukraińskich nacjonalistów w kontekście idei Sojuszu Bałtycko-Czarnomorskiego rozwinęła się pod wpływem Narodowego Manifestu, podpisanego w marcu 2017 r. przez liderów największych nacjonalistycznych sił ukraińskich - Swobody, Prawego Sektora i Korpusu Narodowego. Pierwszym punktem manifestu było zapewnienie, że priorytetem polityki państwowej Ukrainy ma być obrona interesów narodowych państwa. Z kolei już drugi punkt manifestu mówił o tym, że Ukraina ma wypracować nowy geopolityczny wektor - utworzenie nowej europejskiej integracji - Sojuszu Bałtycko-Czarnomorskiego ${ }^{19}$.

Wsparcie regionalnego sojuszu bliskiego ideowo do Sojuszu Bałtycko-Czarnomorskiego znajdziemy u Micheila Saakaszwilego, który w książce Przebudzenie mocy opisał swoją wizję podobnego projektu (w momencie napisania książki Saakaszwili był przewodniczącym Odeskiej Obwodowej Administracji Państwowej). W porównaniu z większością innych koncepcji Saakaszwili dużo uwagi w tym kontekście poświęcił Turcji. W projekcie widział również jako uczestników potencjalnego sojuszu państwa Kaukazu. Także i on postrzegał ten sojusz jako alternatywę dla "starej Europy”.

Turcja to bardzo silny kraj. Myślę, że ona powinna odğrywać ważną rolę w sojuszu regionalnym, do którego wejdą Azerbejdżan, Gruzja, Ukraina, Polska, kraje bałtyckie. [...] Taki regionalny sojusz jest całkiem naturalny, ponieważ nasze państwa mają wspólne interesy. Lech Kaczyński prawie to osiągnął, ale na Ukrainie doszedł do władzy Janukowycz. Europa jest dzisiaj słaba [...]; jestem pewien, że w ciągu najbliższych miesięcy polityczni liderzy Europy spróbują osiągnąć porozumienia z Putinem. Jedyne wyjście dla nas to nie koncentrować się na tym, co mówią w Berlinie i Paryżu, ale budować sojusz regionalny [...]. Ukraina musi szukać wspólnego języka z Turcją i przyjąć na siebie rolę lidera

19 Nacionalnyj manifest, Swoboda [online], 16 III 2017 [dostęp: 17 XI 2019], dostępny w internecie: $<$ https://svoboda.org.ua/news/natsionalisty-pidpysaly-ta-predstavylynatsionalnyj-manifest $/ 114270 /\rangle$. 
w stosunkach z Kaukazem i Mołdawią, a razem z Polską - w stosunkach z państwami bałtyckimi [...]. My cały czas patrzymy na Berlin i Paryż i to jest nasz błąd. Negocjacje z tymi stolicami będą coraz mniej skuteczne, a nieprzyjemnych niespodzianek będzie coraz więcej ${ }^{20}$

- pisał Saakaszwili.

Reagując na propozycję Andrzeja Dudy utworzenia sojuszu regionalnego, która pojawiła się w trakcie kampanii wyborczej w 2015 r., długi artykuł na temat Sojuszu Bałtycko-Czarnomorskiego opublikował Oleksandr Maslak, ukraiński politolog członek Narodowego Korpusu ${ }^{21}$. W sierpniu 2015 r. Maslak napisał artykuł "Międzymorze" - pomiędzy projektem a rzeczywistościa, w którym, po pierwsze, uznał pomysł sojuszu regionalnego Dudy za kontynuację idei Międzymorza, po drugie, podkreślił, że korzenie tego pomysłu sięgają dzisiaj antyrosyjskiego i antyniemieckiego sentymentu elektoratu Prawa i Sprawiedliwości ${ }^{22}$. Niemniej politolog zauważył, że nie warto oczekiwać gwałtownych zmian w polskiej polityce zagranicznej, ponieważ poszerzenie współpracy w ramach Międzymorza o powołanie wspólnej organizacji wojskowej wywołałoby protest zarówno ze strony państw UE, jak i różnych stron polskiej polityki: liberałów i skrajnej prawicy (według autora ideowych potomków Romana Dmowskiego). Maslak podkreślił również, że Międzymorze nie jest nową ideą, ponieważ o tej koncepcji geopolitycznej pisał Leszek Moczulski na początku lat dziewięćdziesiątych. Odwołał się też do postulatów działaczy Ukraińskiej Republikańskiej Partii o potrzebie utworzenia międzynarodowej inicjatywy podobnej do Międzymorza. Ukraiński politolog zaznaczył jednak, że w ostatnich dziesięcioleciach idea integracji bałtycko-czarnomorskiej została zastąpiona koncepcjami integracji europejskiej i euroazjatyckiej. Według Maslaka zdarzenia geopolityczne ostatnich lat (przede wszystkim aneksja Krymu i początek wojny w Donbasie) odnowiły zainteresowanie i pokazały aktualność integracji na osi bałtycko-czarnomorskiej. Maslak wymienił także ewentualne zalety

20 M. Saakaszwili, Probużdienije siły, Char'kow, „Folio” 2016, s. 261-262.

21 We wrześniu $2017 \mathrm{r}$. Maslak zginął tragicznie w wypadku samochodowym, wracając z konferencji w Warszawie.

22 O. Masłak, Miżmorja - miż proektom ta realnistiu, Banderivets [online], 14 VIII 2015 [dostęp: 17 XI 2019], dostępny w internecie: <http://banderivets.org.ua/mizhmor-ya-mizh-proektom-ta-realnistyu.html>. 
i wady integracji państw Międzymorza. Zaletą byłoby dogodne położenie geopolityczne, ze względu na ważne szlaki transportowe i energetyczne, które leżą na osi bałtycko-czarnomorskiej, oraz podobieństwo „etnicznych mentalności" i norm kulturowych narodów regionu.

Jeśli chodzi o wady takiego ewentualnego sojuszu, Maslak wskazał historyczne spory między państwami regionu. Również dużą wadą według autora byłaby chęć sprawowania hegemonii w sojuszu, która mogłaby się pojawić zarówno w Polsce, jak i na Litwie czy na Ukrainie. Oprócz tego Maslak zauważył, że państwa ewentualnego sojuszu w niewielkim stopniu znają życie codzienne sąsiadów: Polacy niewiele wiedzą o Ukraińcach, Ukraińcy o Litwinach, Litwini o Polakach itd. Jednak największą wadę ewentualnego sojuszu Maslak widział w braku wspólnej geopolitycznej wizji przyszłości regionu. Mimo to, kończąc publikację, wyraził nadzieję, że koncepcja Sojuszu Bałtycko-Czarnomorskiego wejdzie w życie ${ }^{23}$.

\section{Reakcja ukraińskiej opinii publicznej na utworzenie Trójmorza}

To właśnie niezrozumienie słów Dudy o ewentualnym sojuszu regionalnym spowodowało duże rozczarowanie ukraińskiej opinii publicznej po utworzeniu w 2015 r. Trójmorza jako wewnątrzunijnej organizacji. Nastroje te były bardzo odczuwalne $\mathrm{w}$ artykule wspomnianej Iryny Wereszczuk "Trójmorze" albo nic o nas, bez nas, który ukazał się w Detector Media jesienią 2016 r. Swoją analizę Wereszczuk zaczęła od zarzucenia ukraińskim mediom, że te zbyt mało uwagi poświęcają utworzeniu nowego dużego sojuszu w regionie wschodnioeuropejskim. Autorka pisała, że polskie media uważają Trójmorze za kontynuację idei Piłsudskiego o Międzymorzu. Nie zgadzała się jednak z tym twierdzeniem, biorąc pod uwagę fakt, że format Trójmorza jest daleki od pomysłu Piłsudskiego ${ }^{24}$. Żywiła przekonanie, że brak Ukrainy wśród uczestników Trójmorza jest w pewnym sensie powtarzaniem pomyłki Partnerstwa Wschodniego, które według autorki dobrze wyglądało na papierze, ale nie było skuteczne w rzeczywistości z powodu

23 Tamże.

24 I. Wereszczuk, «Trymorje» abo Niczoho pro nas bez nas, Ho Detektor Media [online], 31 X 2016 [dostęp: 17 XI 2019], dostępny w internecie: <https://detector.media/blogs/ article/120182/2016-10-31-trimore-abo-nichogo-pro-nas-bez-nas/ $\rangle$. 
braku dobrych mechanizmów współpracy finansowej i gospodarczej oraz brak współpracy w sferze bezpieczeństwa ${ }^{25}$.

W swojej argumentacji autorka pomija jednak fakt, że Trójmorze i Partnerstwo Wschodnie od początku mają zupełnie różne cele. Co więcej, Ukraina jest członkiem Partnerstwa Wschodniego, ale nie Trójmorza. Można krytykować mechanizmy współpracy w ramach Partnerstwa Wschodniego, ale mówiąc o Trójmorzu, musimy najpierw się skoncentrować na sensie istnienia tej organizacji, a dopiero później, wychodząc od tego, mówić o możliwości udziału w niej Ukrainy.

Pomijając ten fakt, warto odnotować, spojrzenie Iryny Wereszczuk na brak Ukrainy wśród członków Trójmorza - dla niej to oznaczało „faktyczne uznanie sfery wpływów Rosji". Powodów takiej decyzji autorka upatruje w tym, że państwa członkowskie Trójmorza mają bardzo zróżnicowany stosunek do Rosji, jak również w polsko-ukraińskich sporach historycznych ostatnich lat ${ }^{26}$.

Wyjście dla Ukrainy Wereszczuk widziałaby z kolei w zaproponowaniu własnej wizji rozwoju sojuszu regionalnego. Jako ewentualne miejsce do przedstawienia własnej koncepcji Wereszczuk (przypomnę, będąca wtedy szefową Międzynarodowego Centrum Badań Bałtycko-Czarnomorskich, a od 2019 r. - posłanką rządzącej partii Sługa Narodu) zaproponowała następny szczyt Trójmorza ${ }^{27}$ (w momencie publikacji jej artykułu szczyt był zaplanowany na czerwiec 2017 r. we Wrocławiu, w rzeczywistości odbył się w lipcu 2017 r. w Warszawie z udziałem Donalda Trumpa), jednak nie wzięła pod uwagę faktu, że Ukraina, niebędąca członkiem Trójmorza, bez specjalnego zaproszenia nie miałaby możliwości zabrania głosu na spotkaniu tej organizacji.

W tym momencie parę słów poświęcę odróżnieniu idei Trójmorza od idei Międzymorza. Paweł Kowal i Agnieszka Orszelska-Stączek, mówiąc o genezie Trójmorza, opisują drogę, jaką przeszła ta inicjatywa od źródła, czyli od idei Międzymorza. Według autorów książki Inicjatywa Trójmorza: geneza, cele, funkcjonowanie różne interesy państw członkowskich Trójmorza doprowadziły do radykalnego odpolitycznienia tej inicjatywy. Wyrażało się to,

25 Tamże.

26 Tamże.

27 Tamże. 
po pierwsze, w zerwaniu z projektami Międzymorza czy Mórz ABC i nawet w rezygnacji z nazwy Międzymorze na rzecz politycznie neutralnego Three Seas Initiative (TSI). Po drugie - w uznaniu, że główne cele inicjatywy są wyłącznie związane ze współpracą gospodarczą i energetyczną, całkowicie pozbawione zaś ambicji politycznych. Dlatego też celowo była pomniejszona rola Polski jako inicjatora projektu - był on prezentowany jako projekt polsko-chorwacki. Wreszcie, po trzecie, założono oparcie inicjatywy wyłącznie na państwach członkowskich UE, co wiązało się z pominięciem Ukrainy $^{28}$. Ukraina nie mogła więc się stać członkiem Trójmorza, ponieważ wynikało to bezpośrednio z natury tej inicjatywy. Brak zrozumienia procesu jej „odpolitycznienia” jest bardzo widoczny w ukraińskich publikacjach na temat Trójmorza. Trójmorze ciągle traktuje się na Ukrainie jako organizację polityczną albo wręcz jako Międzymorze bez Ukrainy.

Drugi szczyt Trójmorza w Warszawie odbił się w ukraińskich mediach głośniejszym echem niż samo utworzenie inicjatywy. W lipcu 2017 r. po szczycie w ukraińskich mediach ukazało się od razu kilka dużych artykułów przedstawiających analizę TSI - to dobry przykład reakcji ukraińskiej opinii publicznej na jej działalność. W pierwszy dzień szczytu, 6 lipca, na stronie internetowej Strana.ua ukazał się duży artykuł poświęcony temu wydarzeniu i ogólnie Trójmorzu. Zacytowano w nim wyjaśnienie dyrektor Centrum Polityki Światowej, Oleny Hetmanczuk, powodu braku Ukrainy wśród uczestników Trójmorza. Hetmanczuk stwierdziła, że „żeby zostać zaproszonym na szczyt Trójmorza, trzeba nie tylko być członkiem UE, ale również nie mieć konfliktu z Rosją ${ }^{29}$. Dodatkowo według słów Hetmanczuk Ukraina nie potrzebuje zbytnio uczestnictwa w Trójmorzu, ponieważ:

[...] mimo zapewnień, że to nie jest alternatywa UE, wielu w Berlinie i Brukseli odbiera tę organizację jako taką [...]. Czy Ukraina potrzebuje problemów w relacjach z Berlinem i Brukselą przez inicjatywę, której praktyczna perspektywa jest wciąż niejasna? Wydaje się, że odpowiedź jest oczywista ${ }^{30}$.

28 P. Kowal, A. Orzelska-Stączek, Inicjatywa Trójmorza..., s. 46.

29 Czto takoje sojuz «Triochmorja» i poczemu tuda nie zowut Ukrainu?, CTPAHA.ua [online], 6 VII 2017 [dostęp:17 XI 2019], dostępny winternecie: <https:/strana.ua/articles/analysis/ 80101-chto-takoe-soyuz-trehmorya-i-pochemu-tuda-ne-zovut-ukrainu.html $>$.

30 Tamże. 
Z kolei redaktor naczelny „Europejskiej Prawdy” Jurij Panczenko, podkreślając infrastrukturalne cele zadeklarowane przy utworzeniu Trójmorza, stwierdził, że to właśnie udział Donalda Trumpa w drugim szczycie wniósł polityczny kontekst do koncepcji projektu. Według Panczenki udział amerykańskiego prezydenta to demonstracja tego, że Trójmorze może być instrumentem USA wpływu na ogólnoeuropejską politykę ${ }^{31}$. Co więcej, w udziale Trumpa w warszawskim spotkaniu Panczenko upatrywał główną przyczynę niezaproszenia Petra Poroszenki na szczyt, ponieważ „możliwość, którą dostała Polska, trzeba było wykorzystać jak najskuteczniej. Przede wszystkim udowodniwszy, że Polska ma prawo pretendować do bycia liderem w regionie ${ }^{32 "}$.

Ciekawą analizę koncepcji Trójmorza i miejsca przy nim Ukrainy zaproponował na zachodnioukraińskiej stronie internetowej Zbruc.eu Wołodymyr Semkiw. Autor uważał, że w pierwotnej idei Trójmorza Ukraina funkcjonowała, nawet jeśli nie jako państwo członkowskie tej inicjatywy, to przynajmniej jako państwo partnerskie. Udowadniając tę tezę, Semkiw mówił, że Ukraina została zaproszona na pierwszy szczyt Trójmorza do Dubrownika. Taką myśl przedstawił Bohdan Hud, którego cytował Semkiw:

\begin{abstract}
Ukraina była zaproszona na pierwsze spotkanie w Chorwacji, ale nikt nie przyjechał. Już kiedy odbyło się spotkanie z prezydentem Trumpem, dopiero wtedy Ukraina zwróciła uwagę na rangę tej inicjatywy. I już wtedy pojawiło się zaniepokojenie, że Ukraina nie została zaproszona. Ale w polityce nie ma drugorzędnych aspektów. Każda inicjatywa nagle może stać się znacząca. Trzeba pilnie śledzić procesy w polityce światowej i adekwatnie reagować na zaproszenia ${ }^{33}$.
\end{abstract}

Dalej Semkiw powołał się na punkt widzenia Hałyny Jaworskiej, ekspertki państwowego Narodowego Instytutu Badań Strategicznych, która przyczynę nieobecności Ukrainy na szczycie w Dubrowniku widziała raczej w tym, że Trójmorze tworzą tylko państwa UE i „mimo

31 Dwa warianty dla Trymorja: czomu nastupnyj forum ważtywiszyj dla Ukrajiny za warszawśkyj, Ewropejska prawda [online], 10 VII 2017 [dostęp: 17 XI2019], dostępny w internecie: 〈https://www.eurointegration.com.ua/experts/2017/07/10/7068310/〉.

32 Tamże.

33 Iluzija Miżmoria, Zbruc [online] 22 VII 2017 [dostęp: 17 XI 2019], dostępny w internecie: 〈https://zbruc.eu/node/68720 >. 
deklarowanego skierowania projektu na cele infrastrukturalne i gospodarcze Trójmorze ma wyraźny wymiar polityczny" ${ }^{\prime 3}$. Oprócz tego jedną z przyczyn braku zaproszenia Ukrainy według Jaworskiej są trudności w stosunkach polsko-ukraińskich, natomiast najważniejszą „wewnętrzna przebudowa Unii Europejskiej”35; przebudowa, w ramach której Trójmorze jest próbą znalezienia alternatywnych sposobów transformacji UE w przeciwieństwie do „polityki różnych prędkości”, proponowanej co prawda przez państwa "starej Europy”, ale bez wsparcia Europy Wschodniej, przede wszystkim zaś Polski.

O zignorowaniu zaproszenia na szczyt Trójmorza w Dubrowniku wspominali również były ambasador Ukrainy w USA i Izraelu Jurij Szczerbak ${ }^{36}$ oraz Olena Hetmanczuk ${ }^{37}$.

Jeżeli patrzeć na Trójmorze jako na element wewnątrzunijnej gry politycznej, staje się jasne, dlaczego na razie dla Ukrainy nie ma miejsca $\mathrm{w}$ tym projekcie. Ta inicjatywa jest bowiem traktowana jako przedsięwzięcie wewnątrz UE. Podobnie jak stanowisko Oleny Hetmanczuk także zdanie Hałyny Jaworskiej w tej kwestii jest jednoznaczne:

Nie warto spieszyć z tematem dołączenia do nowych inicjatyw regionalnych, ponieważ z tym mogą być powiązane nowe wyzwania i ryzyko w stosunkach Ukrainy z Brukselą, Berlinem i Paryżem ${ }^{38}$.

W pracy Semkiwa cytowana jest także wypowiedź Iryny Wereszczuk:

Idea Trójmorza deklarowana przez Andrzeja Dudę nie jest tym formatem, który byłby dobry dla Ukrainy. Najlepszą możliwością dla Ukrainy jest utworzenie szerokiego aliansu, ale nie jako politycznego sojuszu,

34 Tamże.

35 Tamże.

36 Posol rozpowiw, czomu Ukrajinu ne zaprosyly na konferenciju Trymorja, 5 kanał [online], 6 VII 2017 [dostęp: 18 X 2020], dostępny w internecie: <https://www.5.ua/ polityka/posol-rozpoviv-chomu-ukrainu-ne-zaprosyly-na-konferentsiiu-trymoria149650.html>.

37 Czomu samit Trymorja startuwaw u Polszczi bez Poroszenka - reakciji ta komentari, Portal Polsko-Ukraiński [online, dostęp: 18 X 2020], dostępny w internecie: <http:// www.polukr.net/uk/blog/2017/o7/chomu-samit-trimor-ya-startuvav-u-polshhi-bezporoshenka-reakciyi-ta-komentari/>.

38 Tamże. 
który dzieliłby Unię Europejską. Bo niczego lepszego od UE na razie nie ma i trzeba bronić jej integralności ${ }^{39}$.

Z kolei w opublikowanym w lipcu 2016 r. artykule Bohdan Hud dostrzegał, że po utworzeniu Trójmorza nikt nie będzie zainteresowany powołaniem kolejnej regionalnej struktury, tym bardziej że stosunki polsko-ukraińskie nie były wówczas najlepsze.

Zgodziła się z nim Hałyna Jaworska, zdaniem której warto szukać formatów praktycznej współpracy z Trójmorzem w sferze gospodarki i infrastruktury. Nie wyjaśniła jednak, jakie mogą być te formaty. W odróżnieniu od Partnerstwa Wschodniego jak dotychczas żadnych instrumentów podobnej współpracy Trójmorza z państwami spoza tej organizacji nie było.

Kolejny wzrost zainteresowania Trójmorzem przypadł na wrzesień 2018 r., kiedy odbył się trzeci szczyt organizacji w Bukareszcie. Dwa tygodnie przed szczytem na Forum Gospodarczym w Krynicy ówczesny minister rozwoju gospodarczego i handlu Ukrainy Stepan Kubiw powiedział, że:

[...] nie jest możliwe, żeby Ukraina dzisiaj nie była częścią Międzymorza [najprawdopodobniej Kubiw miał na myśli Trójmorze - O.S.], ponieważ jest ona obecnie wskaźnikiem mającym przede wszystkim charakter ludzki i polityczny, jak również gospodarczy. Jesteśmy mocniejsi razem, tym bardziej że agresja [Rosji] wciąż się nie skończyła. Dzisiaj mamy realnego agresora w postaci Rosji. Sprawy Ukrainy są wezwaniem dla całej Europy i świata, ponieważ Ukraina stała się swoistym gwarantem stabilizacji i powstrzymania drugiej armii na świecie ${ }^{40}$.

W pierwszym dniu szczytu Trójmorza w Bukareszcie na łamach „Europejskiej Prawdy” ukazał się artykuł Tetjany Lewonuk, ekspertki centrum analitycznego Nowa Europa, m.in. o możliwościach współpracy Ukrainy z Trójmorzem. Istotny jest zwłaszcza fragment:

39 Tamże.

40 Kubiw pojasnyw, czomu Ukrajina powynna wchodyty do proektu Trymorja, Ukrinform [online], 4 IX 2018 [dostęp: 17 XI 2019], dostępny w internecie: <https://www.ukrinform.ua/rubric-polytics/2530834-kubiv-poasniv-comu-ukraina-povinna-vhoditi-doproektu-trimora.html>. 
Przede wszystkim Ukraina ma możliwość dołączenia do niektórych projektów infrastrukturalnych i w ten sposób może realizować politykę integracji europejskiej nie deklaratywnie, ale w praktyce [...]. Oprócz tego wykorzystanie Trójmorza jako przestrzeni do stworzenia efektywnej komunikacji z zachodnimi sąsiadami w kwestiach dotyczących wspólnego interesu będzie korzystne dla wzmocnienia pozycji Ukrainy w regionie Europy Środkowej i Wschodniej ${ }^{41}$.

W taki sposób Lewonuk powtórzyła tezy Hałyny Jaworskiej i Bohdana Huda o możliwości wykorzystania Trójmorza do realizowania pewnych projektów infrastrukturalnych i gospodarczych.

Dwa dni później, po zakończeniu szczytu w Bukareszcie, „Europejska Prawda" opublikowała artykuł Markijana Łubkiwskiego, ukraińskiego polityka, byłego doradcy szefa SBU oraz dyrektora ukraińskiej części Euro 2012. Według niego spotkanie w Bukareszcie stało się jaskrawym przykładem „budowania architektury bilansu wewnątrz UE”. Z jednej strony na szczycie był obecny ówczesny przewodniczący Komisji Europejskiej Jean-Claude Juncker i minister spraw zagranicznych Niemiec Heiko Maas, z drugiej - interesy Stanów Zjednoczonych przedstawiał minister energetyki Rick Perry. Z punktu widzenia Łubkiwskiego to dowód na to, że Trójmorze, mimo oczywistego wsparcia ze strony USA, nie dzieli, lecz wzbogaca Unię Europejską. Mówiąc o relacjach Ukrainy z Trójmorzem, Łubkiwski zauważył, że brak przedstawiciela Ukrainy na pierwszym szczycie w Dubrowniku to "wielka polityczna i dyplomatyczna pomyłka”. Polityk uważał, że to wtedy Ukraina miała możliwość stać się jednym ze współzałożycieli Trójmorza. Mimo to dostrzegał, że warto wziąć udział w szczycie w Lublanie latem 2019 r. i postarać się o status państwa partnerskiego. Według Łubkiwskiego, żeby to się udało, należałoby przygotować pakiet projektów (przede wszystkim infrastrukturalnych, które mogłyby zainteresować państwa Trójmorza ${ }^{42}$ ).

41 Konkurenty Ukrajiny czy dweri do JES: czym może staty dla nas iniciatywa Trymorja?, Ewropejska prawda [online], 17 IX 2018 [dostęp: 17 XI 2019], dostępny w internecie: <https://www.eurointegration.com.ua/articles/2018/09/17/7087014/>.

42 Ukrajina w storoni wid trioch moriw:czomu Kyjiw ihnoruje iniciatywu zmiliardamy inwestycij?, Ewropejska prawda [online], 19 IX 2018 [dostęp: 17 XI 2019], dostępny w internecie: 〈https://www.eurointegration.com.ua/articles/2018/09/19/7087102/>. 


\section{Podsumowanie}

W ramach podsumowania należy podkreślić, że po Euromajdanie temat Sojuszu Bałtycko-Czarnomorskiego powrócił do dyskursu politycznego na Ukrainie, a po utworzeniu Trójmorza - rozwinął się i zaowocował konkretnymi analizami politologów, dotyczącymi możliwości rozwoju stosunków Ukrainy z tą inicjatywą. Poszczególni autorzy reprezentowali kilka tendencji.

U kilku z nich tendencją okazała się ostrożność w odbiorze Trójmorza jako inicjatywy, która jest niezbyt dobrze przyjmowana przez państwa starej Europy. Cechą charakterystyczną dla sceptyków Trójmorza jest odbieranie jej jako takiej, która w pewnym sensie przeciwstawia się Unii Europejskiej i jest formą wschodnioeuropejskiej alternatywy UE albo instrumentem wpływów USA w Europie. Zwolennicy takiej pozycji zazwyczaj dystansowali się od pomysłu współpracy Ukrainy z Trójmorzem, mając obawy przed skutkiem $\mathrm{w}$ postaci ewentualnego napięcia w stosunkach Ukrainy z zachodnimi sojusznikami.

Jeszcze jedna tendencja polegała na odbieraniu działalności Trójmorza jako formuły politycznej i doszukiwaniu się politycznych intencji w procesach związanych z powstawaniem Trójmorza. To podejście paradoksalnie było charakterystyczne zarówno dla sceptyków, jak i dla zwolenników współpracy Ukrainy z Trójmorzem. W tym ujęciu inicjatywa ta nie jest traktowana jako tylko projekt infrastrukturalny, ale przede wszystkim polityczny, a nawet obronny, a jego motywem miałaby być idea przeciwstawienia się presji rosyjskiej.

W związku z tym widoczna jest tendencja do popierania zacieśnienia współpracy Ukrainy z państwami członkowskimi Trójmorza w dziedzinie gospodarki i infrastruktury. Znajdujemy to w tekstach Hałyny Jaworskiej, Tetiany Lewoniuk i Markijana Łubkiwskiego.

Należy zauważyć, że zainteresowanie kwestią ewentualnej współpracy na osi bałtycko-czarnomorskiej, nie tylko w kontekście Trójmorza, jest charakterycztyczne dla przedstawicieli całkiem różnorodnych, a nawet wrogich wobec siebie ukraińskich sił politycznych. W przedstawionym artykule wspominaliśmy w tym kontekście zarówno o prawicowych partiach Prawy Sektor i Swoboda, jak i o Bloku Petra Poroszenki, oraz obecnie rządzącej partii Sługa Narodu. Cytowany zaś Markijan Łubkiwskij jest doradcą szefowej partii Batkiwszczyna Julii Tymoszenko. Niejednokrotnie o zainteresowaniu tematem współpracy na osi bałtycko-czarnomorskiej 
mówił były przewodniczący Rady Najwyższej z ramienia Frontu Ludowego Andrij Parubij, obecnie posłem partii Europejska Solidarność powiązanej z Petrem Poroszenką. Można powiedzieć, że tematem TSI interesują się wszystkie główne ukraińskie siły polityczne oprócz prorosyjskich.

Warto zauważyć również koncentrację na kwestii nieobecności Ukrainy na szczycie w Dubrowniku za błąd ukraińskiej dyplomacji. Znajdujemy tę myśl u kilku autorów. Brak przedstawiciela Ukrainy na szczycie w Dubrowniku faktycznie zamknął możliwość dalszej współpracy z tą organizacją, ponieważ nie wypracowano odpowiedniego formatu, który uwzględniałby obecność Ukrainy, a następnie Trójmorze ukształtowało się jako organizacja złożona z państw członków UE.

$\mathrm{Z}$ powyższej analizy wynikają następujące postulaty badawcze: interesujące byłoby kontynuowanie badań nad przedstawioną tematyką oraz porównanie reakcji na powołanie Trójmorza i oczekiwań od tej inicjatywy w Polsce i na Ukrainie. Pomogłoby to lepiej zrozumieć różnice w pojmowaniu obecnej rzeczywistości geopolitycznej. Ważne byłoby dalsze badanie opinii na temat możliwości rozszerzenia Trójmorza, $w$ tym współpracy z państwami spoza UE. Brakuje analiz na temat reformowania Trójmorza, chociaż potencjał tej organizacji we współdziałaniu ze wschodnimi sąsiadami jest olbrzymi. Przede wszystkim skuteczna może być współpraca energetyczna pomiędzy Ukrainą a Trójmorzem.

W ostatnich latach coraz bardziej widoczne są sprzeczności pomiędzy Polską a Ukrainą w podejściu do sytuacji politycznej w regionie. Chodzi o konflikty historyczne, ale też o takie kwestie jak rozszerzenia formatu normadzkiego, do którego w swoim czasie Polska miała ambicje dołączyć. Dotyczy to również traktowania Trójmorza. Te wszystkie sprzeczności doprowadzają do braku faktycznie skutecznego współdziałania polsko-ukraińskiego w wielu perspektywicznych obszarach. Dlatego niezbędne wydaje się gruntowne badanie porównawcze stosunków polsko-ukraińskich pod względem wzajemnych oczekiwań i wizji geopolitycznej sytuacji w Europie.

\section{Bibliografia}

Batto-Czornomorśkyj Sojuz, jak alternatywa zachidnomu wektoru, Informacyjna agencja "Whołos” [online], 13 IV 2014 [dostęp: 2 XI 2019], dostępny w internecie: $<$ https://vgolos.com.ua/articles/balto-chornomorskyj-soyuz-yak-alternatyvashidno-zahidnomu-vektoru_142465.html $>$. 
Czomu samit Trymorja startuwaw u Polszczi bez Poroszenka - reakciji ta komentarz, Portal Polsko-Ukraiński [online, dostęp: 18 x 2020], dostępny w internecie: <http://www.polukr.net/uk/blog/2017/o7/chomu-samit-trimor-ya-startuvav-upolshhi-bez-poroshenka-reakciyi-ta-komentari/>.

Czto takoje sojuz "Triochmorja» i poczemu tuda nie zowut Ukrainu?, CTPAHA.ua [online], 6 VII 2017 [dostęp: 17 XI 2019], dostępny w internecie: <https://strana. ua/articles/analysis/80101-chto-takoe-soyuz-trehmorya-i-pochemu-tuda-nezovut-ukrainu.html>.

Druhyj Battijśko-Czornomorśkyj Forum [online], 10 III 2017 [dostęp: 17 XI 2019], dostępny w internecie: 〈https://centrebbs.org/fr/vtoroj-forum/>.

Dwa warianty dla Trymorja: czomu nastupnyj forum ważływiszyj dla Ukrajiny za warszawśkyj, Ewropejska prawda [online], 10 VII 2017 [dostęp: 17 XI 2019], dostępny w internecie: 〈https://www.eurointegration.com.ua/experts/2017/07/10/7068310/>.

Hromadśka orhanizacija Battijśko-Czornomorśka Konfederacija, YouControl [online], 23 II 2015 [dostęp: 17 XI 2019], dostępny w internecie: <https://youcontrol.com. ua/catalog/company_details/39653694/>.

Iluzija Miżmoria, Zbruc [online], 22 VII 2017 [dostęp: 17 XI 2019], dostępny w internecie: 〈https://zbruc.eu/node/68720>.

Informacijnyj centr "Miżmorja» - pro nas, Informacijnyj centr "Miżmorja” [online, dostęp: 2 XI 2019], dostępny w internecie: 〈https://intermarium.in.ua/about/〉.

Jurydyczni aspekty utworennia Battijśko-Czornomorśkoji Konfederaciji, ar25.org [online], 1 XII 2015 [dostęp: 17 XI 2019], dostępny w internecie: <https://www. ar25.org/article/yurydychni-aspekty-utvorennya-baltiysko-chornomorskoyikonfederaciyi.html>.

Juryneć O. W., Nowi heopolityczni wykłyky jak pidstawa formuwannia BałtijśkoCzornomorśkoji Osi // Bałto-Czornomorśkyj Sojuz: wid mifu do realnosti, Kyjiw 2017, s. 3-4.

Konkurenty Ukrajiny czy dweri do JES: czym może staty dla nas iniciatywa Trymorja?, Ewropejska prawda [online], 17 IX 2018 [dostęp: 17 XI 2019], dostępny w internecie: 〈https://www.eurointegration.com.ua/articles/2018/o9/17/7087014/>.

Korolow H. O., Ideja czornomorśkoji federaciji u pohladach Mychajła Hruszewśkoho // „Ukrajinśkyj istorycznyj żurnał” 2011, № 6, s. 68-79.

Kowal P., Orzelska-Stączek A., Inicjatywa Trójmorza: geneza, cele, funkcjonowanie, Instytut Studiów Politycznych PAN, Warszawa 2019, s. 20.

Kubiw pojasnyw, czomu Ukrajina powynna wchodyty do proektu Trymorja, Ukrinform [online], 4 IX 2018 [dostęp: 17 XI 2019], dostępny w internecie: <https://www. ukrinform.ua/rubric-polytics/2530834-kubiv-poasniv-comu-ukraina-povinnavhoditi-do-proektu-trimora.html $>$.

Łypa J., Czornomorśka doktryna [online, dostęp: 19 X 2020], dostępny w internecie: 〈https://diasporiana.org.ua/wp-content/uploads/books/21865/file.pdf〉.

Masłak O., Miżmorja - miż proektom ta realnistiu, Banderivets [online], 14 VIII 2015 [dostęp: 17 XI 2019], dostępny w internecie: <http://banderivets.org.ua/mizhmor-ya-mizh-proektom-ta-realnistyu.html $>$. 
Miżnarodna konferencija $w$ Hadiaczi, oficjalna strona internetowa Hadziackiego rejonu [online, dostęp: 17 XI 2019], dostępny w internecie: 〈http://www.hadiach-rajon-vlada.org.ua/index.php/1899-mizhnarodna-konferentsiya-u-gadyachi > Nacionalnyj manifest, Swoboda [online], 16 III 2017 [dostęp: 17 XI 2019], dostępny w internecie: <https://svoboda.org.ua/news/natsionalisty-pidpysaly-ta-predstavyly-natsionalnyj-manifest/114270/ $>$.

Posoł rozpowiw, czomu Ukrajinu ne zaprosyły na konferenciju Trymorja, 5 kanał [online], 6 VII 2017 [dostęp: 18 X 2020], dostępny w internecie: <https://www.5.ua/ polityka/posol-rozpoviv-chomu-ukrainu-ne-zaprosyly-na-konferentsiiutrymoria-149650.html>.

Program wyborczy partii Prawy Sektor, Centralna Komisja Wyborcza [online], 26 X 2014 [dostęp: 17 X 2020], dostępny w internecie: <https://www.cvk.gov.ua/pls/ vnd2014/wp502ptoo1fo1=910pf $7171=158 . \mathrm{html}>$.

Program wyborczy partii Swoboda, Centralna Komisja Wyborcza [online], 22 IX 2014 [dostęp: 2 VI 2019], dostępny w internecie: <https://www.cvk.gov.ua/pls/ vnd2014/wp502ptoo1fo1=910pf $7171=155 \cdot \mathrm{html}>$.

Saakaszwili M., Probużdienije sity, Char'kow, „Folio” 2016, s. 261-262.

Tretij Battijśko-Czornomorśkyj Forum [online], 23 VI 2017 [dostęp: 17 XI 2019], dostępny w internecie: 〈https://centrebbs.org/fr/tretij-forum/〉.

Ukrajina $w$ storoni wid trioch moriw: czomu Kyjiw ihnoruje iniciatywu $z$ miliardamy inwestycij?, Ewropejska prawda [online], 19 IX 2018 [dostęp: 17 XI 2019], dostępny w internecie: <https:/www.eurointegration.com.ua/articles/2018/o9/ 19/7087102/>.

Wereszczuk I., «Trymorje» abo Niczoho pro nas bez nas, Ho Detektor Media [online], 31 X 2016 [dostęp: 17 XI 2019], dostępny w internecie: <https://detector.media/ blogs/article/120182/2016-10-31-trimore-abo-nichogo-pro-nas-bez-nas/>.

Zajawa uczasnykiw 1-ho Battijśko-Czornomorśkoho Forumu Konfederacija [online], 1 XII 2016 [dostęp: 17 XI 2019], dostępny w internecie: <https://centrebbs.org/ fr/pervyj-forum/>.

Zbrucz A, Ideja Bałto-Czornomorśkoho Sojuzu (Miżmorja): istorija ta perspektywy [online], 25 V 2017 [dostęp: 14 VI 2020], dostępny w internecie: <https://pravyysektor.info/ prosvitnyctvo/oriyentyry/ideya-balto-chornomorskogo-soyuzu-mizhmoryaistoriya-ta-perspektyvy $>$. 